\title{
THE TALENT OF MATURE WOMEN AND THEIR LEGACY FOR HUMANITY
}

\author{
MARINA TRONCOSO-RODRÍGUEZ \\ Senior Graduate, Vigo University,Spain \\ García Barbón 112, 36201 Vigo, Spain \\ E-mail address: mtroncosor@yahoo.es
}

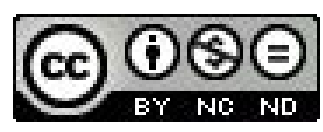

\begin{abstract}
This paper is a compilation of facts about women who shone in their youth either for their research, their works of art, or their social and political activities, and who remained active in their later years, when they became what are commonly called senior citizens. It was during these years that these brilliant women managed to crystallise and consolidate the work they had done all of their life, bringing about changes in scientific, artistic, cultural and social fields, and leaving behind a legacy of knowledge for future generations.

A small group of women representing different disciplines has been chosen here, and all of these women were active in their later life. Many others who could have been included will not be found, not only because there is not enough space here to mention all of them but also because there is a lack of sources dealing with the millions of senior heroines who are anonymous; elderly women who play a vital role in the development of humanity when they pass on knowledge and values; women who remain active in their later years and who only retire the day they die.
\end{abstract}

Key words: elderly woman, contribution, active ageing

\section{INTRODUCTION}

At the beginning of the 21st century the rights of the vast majority of women in the world (some 3.700 million) were consistently being ignored or violated. 15 years later, in 2016, nothing has changed. Women who are lucky enough to be born in countries in which the law establishes equal rights and duties for both sexes usually have to struggle so that such laws should be obeyed, because although they are written on paper, they are not followed in the real world. Women are paid less for the same job, have fewer chances to reconcile their professional and private lives, and have to overcome all sorts of hurdles for reasons of gender, and have to face even harder odds as they grow older. But it has been elderly women who have embraced new models of society and elderly women who have passed on a legacy of culture and values to their children and grandchildren. And it has always been women who have nur- 
tured the emotional balance of society from the privacy and invisibility of their homes, contributing to the well-being of society by offering support and comfort on a daily basis.

One of the many injustices that women have to put up with is that many outstanding women in the world of the arts, science and in the humanities should have been overlooked or viewed with contempt. Even worse, some of them had to hide behind men who took advantage of their genius in a society that refused to let them take centre stage, women like Rosalind Franklin, who discovered the structure of life without ever getting the recognition she so much deserved.

Out of all of these women, those who managed to live to an older age continued to work in the field they had devoted their lives to, actively ageing while expanding their knowledge, spreading their wisdom and sharing their work with the rest of us for the good of all society.

\section{KEY FIGURES}

The most prestigious award on the planet, the Nobel Prize, has seldom been given to women. The first one to get the prize was Polish Maria Salomea Skłodowska (Marie Curie) (Warsaw, Poland, November 7 1867, Passy, France, July 4 1934), who won the prize for Physics along with her husband Pierre Curie and Henri Becquerel in 1903. She is also the only woman who has won the Nobel Prize on two separate occasions, since she received the Nobel Prize for Chemistry in 1911. Her daughter, Irène Joliot-Curie, won the Nobel Prize for Chemistry in 1935, the only time a mother and daughter have both won the prize. Marie discovered two new elements: Polonium (which she named after her homeland, Poland) and radium. The use of radium has been crucial in humanitarian efforts using medicine. During the First World War Marie put together, with the help of private donations, a team of experts in radiology, and with the aid of her daughter Irene, they equipped two hundred radiological vehicles. Both mother and daughter went to the Front in order to teach doctors all about the new techniques and methods being used in radiology. Struggling against the misogamy prevalent in her day, she made discoveries and did groundbreaking work that led to key advances in science; historian Tadeusz Estreicher, in Polski stownik biograficzny [Polish biographical dictionary] (1938), is convinced that the trail blazed by the Curies has had a significant impact on world development in the 20th and 21st centuries. Thanks to treatments based on their discoveries, countless people are still being saved today.

Maria Salomea Skłodowska lived until she was 67, immersed in her work and research until the very end.

Selma Ottilia Lovisa Lagerlöf, writer, (Mårbacka, Sweden, November 20 1858-Mårbacka, March 16 1940), was the first woman to get the Nobel Prize for Literature (1909). She remained committed to society until the time of her death. At the age of 81 this indefatigable humanitarian was still trying to do 
her best to help fellow humans, collaborating in the efforts to aid Finnish refugees who were victims of the Soviet military siege during World War II, While doing so this committed woman suffered a massive heart attack that brought her life to an end.

Mother Teresa (Uskub, Ottoman Empire - currently Skopje, Macedonia -, August 261910-Calcuta, India, September 51997), secular name Agnes Gonxha Bojaxhiu, originally from Albania and naturalized Indian. She founded the missionaries of charity in Calcutta in 1950. She took care of the poor, the dying, the sick and the orphaned for more than 45 years until she died aged 87 . She got the Nobel Peace Prize in 1979 when she was 69. She remained devoted to humanitarian aid another 18 years and aged actively while remaining involved. Her legacy continues today and is an example to follow by all those providing aid, dignity and hope to the millions of dispossessed and downtrodden.

Rita Levi-Montalcini (Torino, Italy, April 221909 - Rome, Italy, December 30 2012), neurologist and politician. Her work with Stanley Cohen postulated that cells only proliferate when they receive an order to do so, an order which is transmitted by substances called growth factors, a groundbreaking discovery in medical science. In 1986 while ageing actively, she got the Nobel Prize for Physiology and Medicine. She continued working until she was 102 years old.

Nadine Gordimer, writer, (Springs, Gauteng, South Africa, November 20 1923 - Johannesburg, South Africa, July 13 2014), winner of the Nobel Prize for Literature in 1991, «has been greatly beneficial to humanity through her magnificent epic writing». In her books she deals with interethnic conflict and apartheid. In her later life (she lived until she was 81) she became an activist fighting against HIV and AIDS, raising funds for the Treatment Action Campaign, a group that tries to help sick South Africans gain free access to lifesaving treatments. Gordimer fought relentlessly throughout the whole of her life to defend freedom of expression and denounce censorship, always refusing to connive with spurious powers and continually condemning totalitarian governments.

Doris Lessing, maiden name Doris May Tayler (Kermanshah, Irab, October 221919 - London, England, November 17 2013), also published under the nom de plume Jane Somers and she was a writer, feminist, communist, pacifist and anticolonialist. She won the Nobel Prize for Literature when she was 88 years old. The themes she deals with in her books are cultural conflicts, the flagrant injustice of racial inequality, the contradiction between individual conscience and the greater good. Her work had a significant impact on social change in the 20th century. Lessing transcended labels by shedding light on issues and conflicts that affect all individuals irrespective of gender, ideology or country. She remained active until her death at 94 .

Elinor Ostrom, was an American political economist, (neé Elinor Claire Awan; Los Ángeles, USA, August 71933 - Los Ángeles, June 12 2012). In 2009, when she was 73 years old, she won the Nobel Prize in Economic Sciences, while actively ageing, a prize she shared with Oliver E. Williamson for 
their "analysis of economic governance and organisation of cooperation". The Swedish central bank chose Ostrom for her work saying she had proved that common property can be administered effectively by a group of users and also because of her independent work about "economic governance and the limits of corporations." Ostrom's later work focused on the multivariate nature of the interaction between humans and ecological systems. Her economic theories are applied with views to creating a fairer and more sustainable world economy. She died June 122012 aged 78.

Gertrude B. Elion (New York, USA, January 23 1918- North Carolina, USA, February 21 1999) has gone down in history as one of the most important scientists in the field of medicine. Her research in different disciplines had outstanding results: she synthesized the first treatment for leukemia and the first immunodepressant used in human transplantation, and her work laid down the foundations that led to the development of AZT, a drug used in the treatment of AIDS. Just like many other women working as scientists. she managed to do this in what was definitely a man's world, in which her achievements were overlooked or frowned upon. In 1988, when she was 78 years old, she got the Nobel Prize for Medicine, a late recognition for a woman who had no other choice but to face the prejudice of her day. She remained involved in the dissemination of scientific knowledge until the time of her death. In her own words "in a certain sense a circle has closed since my days as a teacher have led me to get involved in old age in sharing my experience in research with new generations of scientists." Her commitment and effort paid off with the best kind of reward: effective treatments for millions of patients around the world. Her modesty is all the more remarkable when one thinks of the determination she must have had to succeed in a difficult and sometimes hostile environment.

Concepción Arenal, Spanish writer and social activist (Ferrol, Spain, January 211820 - Vigo, Spain, February 4 1893). Negotiating the obstacles women had to face in a time when women were not normally allowed to go to university, she managed to study Law, Sociology, History Philosophy and modern languages in Madrid (even having to disguise herself as a man). She wrote opinion articles in the name of her husband when he was taken ill. Despite the fact that her articles were more acclaimed than those of her husband, when the newspaper found out that she was the author, she was allowed to continue only if her name didn't appear on the articles and as long as she accepted half the money her husband was paid. She did research into the issues and difficulties Spanish women had to face at the time to fulfil their role in human society with dignity. She fought bravely against the prejudice that prevailed against women in those days because of their alleged physiological, moral and intellectual inferiority. She also explored the consequences that no access to education or the workplace had on women. Concepción Arenal helped to give birth to feminism in Spain. She believed that education and access to knowledge would play an essential role in shaping the future of women and equality; her struggle for the equal rights of women blazed the trail for generations to come. 
Svetlana Aleksándrovna Aleksiévich (Ukraine, Soviet Union, May 31 1948), a Russian-speaking writer and journalist from Belarus who got the Nobel Prize for Literature in 2015, the first writer to be awarded the prize for non-fiction in a hundred years. The Swedish Academy cited her "polyphonic verses, a monument to suffering and courage in our days". She remains active in maturity (she is 67) sharing her wisdom and divulging her research.

Florence Nightingale, a British nurse, writer and statistician (Florence, Tuscany, May 12 1820-London, England, August 13 1910) that is considered the pioneer of modern nursing and creator of the first conceptual model of nursing. She laid down the foundations for professionalizing nursing with the establishment of her nursing school at St Thomas' Hospital in London in 1860. This was the first secular nursing school in the world. Her work inspired Henri Dunant, the founder of the Red Cross and author of the humanitarian proposals that were later adopted by the Geneva Convention. Florence Nightingale remained active until her death at age 90.

Vera Rubin, an American astronomer, (Philadelphia, USA, July 23 1928), who pioneered work aimed at measuring the rotation of stars in a galaxy. Her measurements suggested that the rotation curves of galaxies remain flat, contradicting theoretical models, all of which constituted the most direct and sound proof for the existence of dark matter. Vera has contributed with her research and dedication to the development of modern astronomy, opening the door to understanding one of the greatest mysteries in astronomy down through the ages. Rubin is now 87 and she is still working, actively ageing while working as a research astronomer in the Carnegie Institute in Washington.

Ida Noddack, maiden name Ida Eva Tacke, German chemist and physicist, (Lackhausen, German Empire, February 251896 - Bad Neuenahr-Ahrweiler, Western Germany, September 24 1978), was the first scientist to discuss the idea of nuclear fission in 1934 but there has been no recognition of this in scientific circles. She continued to work on her research in her later life until her death at age 82 .

Carolina Herschel (Hannover, Germany, March 161750 - Hannover, January 9 1848), the first "professional astronomer". Together with her brother she discovered a thousand double stars and proved that many of them were binary systems, thereby finding for the first time evidence of the existence of gravity outside the solar system. Apart from working as her brother's secretary, she independently discovered eight comets, three nebulae and she catalogued. She did research and studied stars until her death at age 97 . Her work was only recognised posthumously.

Susan Brownell Anthony (Adams, USA, 1820 - Rochester, USA, 1906) American feminist. Together with Elizabeth Cady Stanton, one of the leaders of the American suffragist movement who fought during the second half of the 19th century so that women could have the right to vote. From the age of 72 to 80 (between 1891 and 1900) she played a pivotal role in the American National Woman Suffrage Association and helped change the social fabric of the world. 
Barbara McClintock, American scientist (Hartford, USA, June 1902 - Huntington, USA, September 1992) specializing in cytogenetics, she discovered the regulating elements of genetic expression and transposition. In 1983, at age 81, she won the Nobel Prize for Medicine or Physiology for her work on transposable elements, 30 years after she had completed it. She remained active in later life and particularly after her biography (written by Everlyn Fox in 1983) she had a substantial influence on public life. She lectured frequently at Cold Spring Harbour to an audience made up of young scientists. She died at age 90.

\section{Senior women in politics:}

- Indira Gandhi, (Allahabad, India, November 1917 - New Delhi, India, October 31 1984), the most powerful leader in India for decades. At the age of 67 , while still highly active, and three months after she had been reelected as Prime Minister of India, she was assassinated.

- Queen Elizabeth II, United Kingdom (Elizabeth Alexandra Mary; London, England, April 21 1926) at age 89 she is still the Queen of England, the United Kingdom and Northern Ireland and head of the Commonwealth, a great example of someone ageing actively.

- Golda Meir (Kiev, Ukraine, May 31898 - Jerusalem, Israel, December 8 1978), in 1969, when she was 71, and actively ageing, she took office as the Prime Minister of Israel.

\section{CONCLUSIONS}

From ninety year-old queens who are still influential in world politics and society, or women like Florence Nightingale whose work laid down the foundations for the Red Cross and the humanitarian proposals of the Geneva Convention, to astronomers who have changed our understanding of the universe with their discoveries, senior women have brought about social change and continue to exercise a positive influence on modern day society, with their writings and condemnation of human injustice and their unflagging support of humanitarian causes aimed at improving the life of the dispossessed and downtrodden, they have raised awareness among millions of people and given birth to a collective conscience focusing on solidarity, transforming the unfair world around them into societies operating on the principles of justice and equality; demanding and defending equal rights for women, doing research and advancing economic measures devised to ensure a fair and sustainable world market economy, actively ageing women are behind scientific discoveries and medical breakthroughs that have saved the lives of millions of human beings and their work over the last century has brought major improvements to the quality of life of countless people. Effective treatments against cancer, immunodepressants used in human organ transplantation, treatments against the AIDS virus or the discovery of the regulating elements involved in genetic 
expressions are all major contributions made by women who were still actively working in their later life.

The greater longevity of women determines a greater number of women among the elderly, a demographic trend that can be seen all across Europe. To give credit to the role played by ageing women in society is a great opportunity. It is a chance to disseminate the truth about the positive role of ageing women in society both in traditional and social media and communication: their activities, their concerns, their problems, their skills and their solidarity. To inform people of their contributions to national economies is an opportunity to give credit to their efforts and tip the scales in favour of the relational economy they are highly invested in rather than yield to prevalent concerns in public opinion about spending. It is also a great chance to make the most of the potential of ageing women to keep on learning, reaching realization in a life project that includes active ageing. Age cannot be construed as a reason to deny people all the rights of full citizenship. Ageing women should not be forced to confront both the barrier of their gender and their age. Age should rather be used as a chance for modern day women to conquer a space which belongs to them because of the contributions they have made to advances in society.

To discuss the activities and abilities of ageing women is important, particularly the role they play in strengthening the intergenerational relations within the family nucleus. Ageing women usually manage to make the most of intergenerational relations adapting more readily to the "modernity" of younger generations and proving to be more flexible to change. This trait encourages them to participate in programmes that foster intergenerational relations outside the framework of family units. Thanks to the experience they have strengthening the emotional and relational ties between different generations in the family, ageing women are able to play a pivotal role in the implementation and development of a society to be enjoyed by people of all ages. The participation of the ageing population and of ageing women in particular should be used to its full potential as a driving force that will help improve living conditions by means of constant dialectics involving representation-participation.

A society for all ages has to be a society in which all of the citizens have full rights of citizenship, in which everyone is represented and in which everyone can participate in balance with the others, and in which no one can be cast out of the public arena due to the fact that they are ageing, or due to the fact that they have stopped working, because in the case of women barriers and ceilings would become twofold and involve both age and gender. This is therefore an opportunity to shed light on the value of ageing women in all of their diversity and heterogeneity, so that they have the final word on how they chose to age, hopefully in a fulfilling and active way that will benefit the whole of society. 


\section{REFERENCES}

[1] All Nobel Prizes. (2016). Retrieved from http://www.nobelprize.org/

[2] Barbara McClintock. (2016). Retrieved from https://es.wikipedia.org/wiki/ Barbara_McClintock.

[3] Berendsohn, W. A. (1968). Selma Lagerlöf: Her Life and Work. Biografía de Concepción Arenal. (2016). Retrieved from http://www.biografiasyvidas.com/biografia/a/arenal.html.

[4] Bonet, P. (2015). La bielorrusa Svetlana Alexiévich, premio Nobel de Literatura. Retrieved from http://cultura.elpais.com/cultura/2015/10/08/actualidad/1444297840_159906.html.

[5] Carolina Herschel. (2016). Retrieved from https://es.wikipedia.org/wiki/Carolina_Herschel.

[6] Comunicado de prensa de The Royal Swedish Academy of Sciences acerca de la otorgación del Premio Nobel de economía 2009: "Economic governance: the organization of cooperation". (2016) Retrieved from http://www.nobelprize.org/nobel_prizes/economic-sciences/laureates/2009/press. html.

[7] Elion, G. B. (2016). La mujer que ganó un Nobel sin tener el doctorado. Retrieved from http:/ / hipertextual.com/2015/03/gertrude-b-elion.

[8] Estreicher, T. (1938). Curie Maria. Polski Stownik Biograficzny [Polish biographical dictionary], IV $, 2,111-114$.

[9] Maydeu, J.A. (2014). Fallece Nadine Gordimer, voz literaria contra el apartheid. Retrieved from http://cultura.elpais.com/cultura/2014/07/14/actualidad/1405343628_541397.html.

[10] Florence Nightingale. (2016). Retrieved from https://es.wikipedia.org/wiki/Florence_ Nightingale.

[11] Goda Meir. (2016). Retrieved from https://es.wikipedia.org/wiki/Golda_Meir.

[12] Ida Noddack. (2016). Retrieved from https://es.wikipedia.org/wiki/Ida_Noddack.

[13] Indira Gandhi. (2016). Retrieved from http://www.biografiasyvidas.com/biografia/g/ gandhi_indira.htm.

[14] Marie Curie. (2016). Retrieved from https://es.wikipedia.org/wiki/Marie_Curie.

[15] Mother Teresa. (2016). Retrieved from https://es.wikipedia.org/wiki/Teresa_de_Calcuta.

[16] Isabel II del Reino Unido (2016). Retrieved from https://es.wikipedia.org/wiki/Isabel_ II_del_Reino_Unido.

[17] Report on older women in Spain. (2011). Ministry of Health, Social Policy and Equality. Government of Spain.

[18] Rita Levi-Montalcini. (2016). Retrieved from https://es.wikipedia.org/wiki/Rita_Levi-Montalcini.

[19] Rubi, V. (2016). Materia oscura, astrónoma brillante. Retreieved from http://www.caosyciencia. com/ideas/articulo.php?id=171209.

[20] Sabogal, W.M. (2013). Muere la escritora Doris Lessing. Retrieved from http://cultura.elpais. com/cultura/2013/11/17/actualidad/1384699418_834154.html.

[21] Selma Lagerlö. (2016). Retrieved from https://es.wikipedia.org/wiki/Selma_Lagerl\%C3\%B6f.

[22] Susan B. Anthony. (2016). Retrieved from https://es.wikipedia.org/wiki/Susan_B._Anthony. 